In one or two instances the animals are painted with their tongues out-reminding one of certain paintings of the eastern Spanish rock-shelter art, as also does the way in which some of the Lascaux animal horns are depicted. These two circumstances back up the contention that a part at any rate of the eastern Spanish art is palæolithic in date. Altamira is the site where the finest Magdalenian paintings have been preserved. Lascaux can claim the same title in respect to the earlier Aurignacian art.

\section{The All-Russian Mineralogical Society}

THe Russian Mineralogical Society is celebrating its hundred and thirtieth anniversary during January 19-25, 1947, in Leningrad. This anniversary is being specially marked, because it was not possible to celebrate appropriately either the centenary or the hundred and twenty-fifth anniversary, since these occurred in 1917 and 1942 respectively. The Society is the oldest mineralogical society in the world-the Mineralogical Society of Great Britain and Ireland was founded in 1876 and the Société Minéralogique de France in 1878. Before the founding of the Geological Committee in 1881 in Russia, the Mineralogical Society was almost the only institution conducting regular geological and mineralogical exploration in that country. It thus became a centre for the collection of information concerning discoveries in little-known Russian regions. Among its most active members have been such brilliant scientific men as N. I. Koksharov, E. E. Chernyshev, E. E. Fedorov and A. Karpinsky. The present chairman of the Council is Academician S. S. Smirnov.

The Society has substantially influenced the development of the science of mineralogy through its publications, which began in 1830 ; they were issued at irregular intervals under various titles until 1866 , when publication commenced of the periodical Notes of the All-Russian Mineralogical Society (Zapiski Vserossiiskogo Mineralogicheskogo Obshchestva). This was the first specialized mineralogical journal in the world ; the Mineralogical Magazine commenced publication in 1877, Bulletin de la Société Minéralogique de France in 1878 and the American Mineralogist in 1916. Later Russian publications were the Bulletins and the Memoirs of the Geological Committee published departmentally (1883) and the Transactions of the Geological and Mineralogical Museum of the Academy of Sciences (1906). The discoveries of Russian mineralogists embodied in the Notes form an essential contribution to the world science of mineralogy. They include such classic memoirs as those by N. I. Koksharov and V. P. Yeremeyev reporting the measurements of minerals, the announcement by A. Gadoin of the discovery of 32 classes of symmetry, E. Federov's work on the discovery of the 230 space groups and many other important papers. The chief tasks of the Society are the exploration of the mineral wealth and soils of the U.S.S.R.; the spreading of mineralogical, geological and palæontological information within the U.S.S.R. ; the establishment of closer contact among Russian men of science working in these fields and facilitating their relations with scientific institutions abroad.

\section{A Monument to Darwin in Uruguay}

IN Nature of July 24, 1937, p. 138, it was recorded that Prof. Karl Walther, of Montevideo, had erected. a stone on the Cerro de los Claveles to commemorate
Darwin's visit to the locality in 1833. The project matured during the years of war, and Walther's original suggestion has now resulted in the erection of a monolith to the memory of Darwin on the summit of the Cerro. The Cerro was Darwin's 'farthest north' in Uruguay, to which he travelled on horseback from Montevideo. Nowadays it is easier to approach it by rail from Montevideo to Mercedes, the capital of the Department of Soriano, and thence by road to the Cerro $50 \mathrm{~km}$. or more to the north-east on the high southern bank of the Rfo Negro at its confluence with the Arroyo Perico Flaco. The nearest village, formerly Saca Chispas, about $5 \mathrm{~km}$. to the south of the Cerro, has been renamed Darwin in honour of the great master. It is a source of much gratification to note how, after more than a hundred years, Darwin's name and fame are still being honoured and acclaimed in Uruguay.

\section{Zoological Society of London: Anatomical Research Fellowship}

THE Council of the Zoological Society of London has decided to re-establish a research fellowship in order to encourage investigations on the comparative anatomy of the animals brought to its prosectorium. The appointment offers unrivalled opportunities for work in this subject, in view of the wealth of material available, amounting during the course of an average year to approximately a thousand mammals, birds, reptiles and amphibians. Some of these animals belong to species likely to become extinct in the near future, and it is most important that some record of their anatomy should be preserved for the benefit of posterity. Also, contrary to the impression sometimes found among professed zoologists that comparative anatomy is an exhausted subject, little is known of the internal structure of any but the commonest animals. The prosectorium of a large zoological gardens offers the only opportunity of helping to fill these gaps in our knowledge. Such investigations are all the more urgent, since the extensive comparative anatomy collection of the Museum of the Royal College of Surgeons, built up mainly by Sir William Flower and his successors, was destroyed during the air raids--probably the worst single scientific loss of the War. It is hoped that the appointment will attract a student to a branch of zoology which, although rather out of fashion in recent times, remains the framework on which its many activities ultimately depend. Further information concerning the fellowship can be obtained from the Secretary, Zoological Society of London, Regent's Park, London, N.W.8.

\section{War Industries and Town Planning}

Two articles, by A. Shenfield and Prof. P. Sargant Florence, reprinted from the Review of Economic Studies (1944-45); hāve a bearing on the siting and development of new towns. The first article, "Labour for the War Industries : the Experience of Coventry", points out that the really important effect of the War upon Coventry is to be seen, not in the physical injuries which the city suffered, but in the conversion of its industries to war purposes and in their expansion to that end. Analysing the character and growth of the population of the city, Mr. Shenfield and Prof. Sargant Florence direct attention to the very high proportion of the workers of Coventry who at the beginning of the War were without roots in the city. This proportion was greatly increased 
by the enforced war-time expansion of its industries, and the existence of a highly abnormal proportion of such newcomers in the population is regarded as aggravating the problems of war-time production; first, because the outward as well as the inward mobility of the immigrant tends to be higher than that of other workers ; and secondly, because with a population largely recruited by the attraction of high earnings and composed of those ready to snatch advantage from slack management, Coventry was likely to show higher costs than some other centres would have done.

In the second paper, "The Economies and Diseconomics of Industrial Concentration: the Wartime Experience of Coventry", analysis of such factors as the cost of labour turnover, absenteeism, higher earnings, transport and housing leads to. the conclusion that the localization since 1939 of war industries in Coventry on the scale required by the Government's plans, and the immigration they involved, was scarcely justified. The fundamental weakness of the Government's original plans was that it did not envisage the economic conditions of total war. The story of Coventry is the story of a war plan framed not merely in, but also to fit, the conditions of peace; and it is by no means certain that it leaves the city fit to meet the conditions of peace to-day. Before the War, Coventry possessed industries which were prosperous and expanding and which, in spite of the seasonal variations of the making of motor-cars, were fairly diversified. Presumably aircraft production will be cut down, and Coventry will depend mainly on the motor-car industry. Unless all the labour imported since 1939 emigrates, Coventry will require a larger motor-car industry than in 1939, since its other pre-war industries may not have been restored. Moreover, at the end of the War, Coventry was specializing more narrowly than before on trades liable to cyclical as well as seasonal fluctuation. Prof. Sargant Florence and Mr. Shenfield conclude that plans should be prepared to guard against abnormally high unemployment. Diversification with industries not liable to cyclical fluctuation and likely to meet post-war demands for durable goods is required, using as a basis the expansion and fostering of offshoots from the electrical, engineering, motal-working and textile industries, so that Coventry approximates in character to its more balanced neighbours, Birmingham and Leicester.

\section{Chemotherapy}

EVERYONE who is interested in chemotherapy should not fail to consult the British Medical Bulletin, No. 4, Vol. 4, 1946, the sub-title of which is "Background to Chemotherapy". Introduced by a sketch of the history of chemotherapy by Dr. E. M. Lourie, this issue of the bulletin contains an article on the steps leading to the therapeutic application of microbial antagonism by Sir Howard Florey, one on the analysis of antibacterial action by Dr. $H$. Macllwain, and a valuable article on the nutrition of bacteria by Sir Paul Fildes. Dr. F. R. Selbie contributes an article on microbial resistance to chemotherapeutic drugs, Prof. L. P. Garrod deals with the principles and practice of local chemotherapy, and Prof. J. H. Gaddum writes on the principles of administration in chemotherapy. Dr. C. H. Andrewes and Dr. Harold King have written a valuable article on the chemotherapy of the rickettsial and virus diseases.
It is good to see that space is also given to the important chemotherapeutical work done in France, which is summarized in an article on the contribution of the Institut Pasteur, Paris, to recent advances in microbial and functional chemotherapy by four members of the staff of this famous institution, Jacques Tréfouël, Mme. Jacques Tréfouerl, Daniel Bovet and Frédéric Nitti. An interesting article by Prof. F. G. Young, entitled "Claude Bernard and Scientific Adventure", pays a just tribute to the work of this great man. The book reviews and the guide to current medical literature continue to be a valuable feature of the bulletin. In this issue there is also a very interesting article on the making of a catalogue of medical films by Dr. Brian Stanford, who is in charge of the reference catalogue of all the films of medical interest in Great Britain, which is being maintained by the co-operation of the Scientific Film Association and the Royal Society of Medicine. Some notes on health education films and some of those produced at the Pasteur Institute are also given.

\section{British Scientific Instrument Research Association}

ONE of the first steps taken in the major scheme of expansion which the British Scientific Instrument Research Association is at present engaged in putting into effect was the creation of an Information Department to serve both members and staff. This Department, in April 1946, began the publication of a printed monthly bulletin, consisting of about twenty pages an issue, and containing Association notes, and abstracts of current, including patent, literature relating to scientific instruments. The bulletin, at first, was circulated only to members of the Association, to whom it is supplied free of charge, but, in order that it may be of the greatest possible use to makers and users of scientific instruments, the Council of the Association has now decided to make the bulletin available to non-members at an annual subscription of $£ 2$.

The October issue of the bulletin (vol. 1, No. 10) records that the work of transferring the Association's research laboratories from Russell Square, London, to new and much larger premises at Chislehurst, Kent, is making good progress, and it is expected that a substantial section of the chemical laboratories will have been removed by the end of November. The response to the request sent out to members for copies of their catalogues and other publications has been very good, and it is hoped to maintain an up-to-date collection of these in the Association's Library. The offices of the Association are at 26 Russell Square, London, W.C.1. The chairman is Dr. W. H. Eccles; the director of research and secretary, Mr. A. J. Philpot; and the information officer, to whom all communications relating to the bulletin and requests for loan of documents should be addressed, is Mr. C. W. Hanson.

\section{Instrument Practice}

WITH the outbreak of hostilities in 1939 a number of important Continental journals disappeared from the literature of instrument technology. Many of these are again becoming available in Great Britain; but there is no doubt that there is room for more published information in this large and varied field of scientific thought. The issue of the first number of a new English publication on instrumentation is, therefore, a matter of great interest. The name of this monthly journal is Instrument Practice, and its title page states that it hopes to cover the whole 